\title{
MUSLIM CUSTOMER BEHAVIOR IN HALAL FOOD ONLINE PURCHASING
}

\author{
Hasan Al-Banna \\ UIN Sunan Kalijaga Yogyakarta, Indonesia, hasan.bana@uin-suka.ac.id
}

\begin{abstract}
While in general people perceive technology based on two major factors: its usefulness and ease of use (Davis, 1989), Muslim customers should consume the food and beverages allowed by the religion. Therefore, nowadays people could purchase anything online including halal food. This paper attempts to examine the Muslim customer behavior in purchasing halal food through online transaction. We modify the original TAM model to adjust to the Muslim customer. We collected the data via self-administered questionnaire, while Partial Least Square structural equation modeling (PLS-SEM) was used to estimate the data. The result shows that perceived usefulness has positive significance to purchase intention. Consequently, religious knowledge has positive significance to habit. Moreover, religious knowledge has positive significant effect to halal label, but has negative significant effect to purchase intention. Otherwise, habit has a significant effect to purchase intention. In addition, perceived ease of use has positive effect to purchase intention. In contrast, halal label has positive insignificant influence to habit. Further, perceived ease of use and perceived usefulness has negative insignificant effect to habit. Furthermore, in this study we also tested habit as mediating variable, the result shows that habit partly mediates between religious knowledge and purchase intention. However, habit failed to mediate between independent variables (perceived usefulness, perceived ease of use and halal label) and dependent variable (purchase intention). Moreover, halal label failed to mediate between religious knowledge and habit. However, further empirical investigation across generation and countries is necessary.
\end{abstract}

Keywords: Perceived Usefulness, Perceived Ease of Use, TAM, Religious Knowledge, Halal Label, Habit, Purchase Intention, Customer Behavior.

JEL Classification: D11; D12; D16; D90; D91.

Article history:

Received : December 4, 2018

Revised : Juli 11, 2019

Accepted : Juli 16, 2019

Available online : November 1, 2019

https://doi.org/10.21098/jimf.v5i3.1152 


\section{INTRODUCTION}

\subsection{Background}

The development of technology in the last decades cannot be ignored, as it comes in and shapes almost everything in human life as a whole including in the business sector (Narwal et. al, 2013). Generally, the evolution of technology transforms the industries and changes the shape of customer behavior (Juaneda-Ayensa et. al, 2016). In the modern world of technology, the landscape of a store in traditional has changed into a virtual store (Koufaris, 2002). Then, the consumer can purchase anything that they want through an online form. Therefore, online behavior can be traced by the numbers of transaction (Renny et. al, 2013).

In addition, people perceive technology based on two major factors: (1) usefulness and (2) ease of use (Davis, 1989). At the same time, the technology acceptance model has been used widely in various studies to analyze customer behavior. Eighty five publications that discuss the model was published (Marangunić \& Granić, 2015), making the TAM model is the best predictor of online customer behavior (Mathieson, 1991). The numbers of empirical investigation was conducted to analyze the online shopping behavior by using TAM model (Tong, 2010) (Hsu, Chang, \& Chuang, 2015)(Akhlaq \& Ahmed, 2015)(Renny et al., 2013) (Wu \& Ke, 2015)(Chi, 2018)(Natarajan, Balasubramanian, \& Kasilingam, 2018) (Driediger \& Bhatiasevi, 2019). However, empirical research relating to online food purchasing is limited (Murat \& Hekimoglu, 2012).

On the other hand, Indonesian consumers are mostly Muslim. Perhaps, they must consume the food and beverages allowed by the religion (halal food). Therefore, the halal label is crucial in the halal food sector. The label helps convince Muslim consumers that they purchase halal food (Razzaque, Mohamed Abdur, 2016)(Rejaii \& Arianfar, 2016). Ultimately, the halal label has a positive impact on food purchasing (Awan et al., 2015)(Aziz \& Chok, 2013) (Ghadikolaei, 2016). Moreover, Muslim customer's behavior determined by their believe of religion (Rahim \& Junos, 2012). Thus, consumption's habit and behavior have become one of believer identity toward religion (Varinli, Erdem, Mutlu, Avcilar, \& Avcilar, 2016). In contrast, the existence of halal label on online form is questioned.

\subsection{Objective}

The existing literature attempts to implement TAM model to predict the online shopping behavior (Tong, 2010) (Lingyun \& Dong, 2008) (Renny et al., 2013) (Ashraf, Thongpapanl, \& Auh, 2014) (Wu \& Ke, 2015) (Jin, Osman, Nizam, \& Rahim, 2016) (Law, Kwok, \& Mark, 2016) (Driediger \& Bhatiasevi, 2019), mobile shopping(Shang, Dawei, Wu, 2017) (Wu \& Wang, 2005) (Chen, Hsu, \& Lu, 2017) (Sohn, 2017) (Natarajan et al., 2018)(Chi, 2018), social media transaction (Hansen, Saridakis, \& Benson, 2018). Further research is necessary in order to apply the model to the Muslim customer in purchasing online halal food. However, empirical investigation relating to purchasing online halal food is limited (Shang, Dawei, Wu, 2017) (Murat \& Hekimoglu, 2012). Therefore, this research addresses the following objectives: (1) to depict the Muslim behavior in purchasing online halal food by using TAM model, (2) to determine the factors with the highest influence of Muslim behavior, (3) to investigate whether it is habitual for Muslim 
customers in purchasing halal food online. Therefore, this research is divided into five sections. In section one, we explore the background of the research. In section two, we review relevant literatures. In section three, we describe empirical methods. In section four, we analyze the empirical findings. In section five, we conclude and recommend.

\section{LITERATURE REVIEW}

In accordance with customer behavior of the Muslim consumer in the digital era, even the emergence of technology has given easy access and use to the human activity, the Muslim consumer should not cross the line of sharia conduct in their behavior in purchasing halal food. Therefore, the religious knowledge of Muslim consumer will be the decision to purchase halal food. However, the Muslim consumer with religious background has been embedded religious value since childhood. Therefore, to behave as permitted as the religion rules is considered as the habit for Muslim consumer (Rahim \& Junos, 2012).

\subsection{Background Theory}

\subsubsection{TAM (Technology Acceptance Model)}

TAM (Technology Acceptance Model) established by (Davis, 1989)(Davis, 1993) was derived from the theory reasoned action (TRA) and theory of planned behavior (TBP) (Marangunić \& Granić, 2015). TAM describes that people behavior depends on how often people use technology (Lee et al., 2003). Therefore, TAM's perceived of usefulness and perceived ease of use determine the decision.

Perceived of usefulness (PU) is the phase to which a person accepts that using technology would enhance their performance. In contrast, perceived of ease of use (PEOU) is the phase to which a person accepts that using technology will be full of easiness (Davis, 1989). In addition, TAM has been used in many fields of study relating to the behavior of consumer in using technology. 85 publications have used the TAM model since it was launched (Marangunić \& Granić, 2015). In essence, compared to theory planned behavior (TPB), TAM model is slightly better in predicting behavioral intention (Mathieson, 1991), not only in predicting behavioral intention, but also intention in smartphone use (Kim, 2014).

Nonetheless, numerous studies revealed that Perceived usefulness (PU) and perceived ease of use (PEOU) have positive effect to consumer's intention to conduct online shopping (Ashraf et al., 2014)(D. L. Amoroso \& Hunsinger, 2009) (Koufaris, 2002)(Driediger \& Bhatiasevi, 2019). Meanwhile, perceived of usefulness directly influences the consumer's intention. In addition, perceived usefulness indirectly influences the consumer's intention through the mediation of attitude. In contrast, perceived ease of use insignificantly influenced the customer's intention, neither indirectly through the mediation of attitude nor directly to customer's intention to shop online (Wu \& Ke, 2015). On the other hand, (Renny et al., 2013) (Ashraf, Thongpapanl, \& Spyropoulou, 2016) found that perceived ease of use and perceived usefulness influence the purchase intention as mediating variable. Then, (Wu \& Wang, 2005)(Natarajan et al., 2018) revealed that only perceived of usefulness which has a positive effect on consumer's intention to use mobile 
commerce. Meanwhile, (Khalifa \& Liu, 2007) stated that perceived usefulness influences the repurchase intention of mobile shopping. Moreover, perceived usefulness also influences the consumer's behavioral intention to purchase halal food (Jamal \& Sharifuddin, 2015). However, in using technology acceptance, men and women differ. While men are influenced by perceived of usefulness, women are influenced by perceived ease of use (Venkatesh, et.al, 2000)(Pascual-miguel, Agudo-peregrina, \& Chaparro-peláez, 2015).

\subsubsection{Religious Knowledge}

Religiosity is referred to the person who believes in their value of religion and applies it in the daily life (Razzaque, Mohamed Abdur, 2016). Therefore, the value of religion and religiosity influences in all aspects of religious people including in their economic activity, such as consumption of food, cosmetics, insurance, and banking (Abd Rahman, Asrarhaghighi, \& Ab Rahman, 2015) (Delener, 1990) (Sukesti, Fatmasari \& Mamdukh, 2014) (Ni. Souiden, 2014) (Souiden \& Rani, 2015).

Empirical investigation showed that religion, religiosity, and the knowledge of it influence the purchase intention. Indeed, religiosity will affect in purchasing decision of religious people (Sukesti, Fatmasari \& Mamdukh, 2014) (Butt, Rose, Stephen, 2015). Then, (Alam, Janor, Zanariah, Wel, \& Ahsan, 2012) (Amin, AbdulRahman, \& Razak, 2014) revealed that religiosity influence the purchase intention to undertake the home financing. Meanwhile, (Minton, Johnson, \& Liu, 2018) (Mohd Suki \& Mohd Suki, 2015) found that religiosity affect the consumption of selecting food. In addition, religious knowledge leads the consumer to select proenvironmental consumer behavior (Bhuian, Shahid Nakib, sujeet, Kumar Sharma, Irfan Butt, Zafar, 2017). Nonetheless, the influence of the value of religion also affects customer loyalty (Swimberghe, Sharma, \& Flurry, 2009). Even though, Muslim consumers have no difference from the western consumer in purchasing luxury goods and conventional finance (Newaz, Farhana, Fam, Kim-Shyan, Revti, 2016) (Nwankwo, Hamelin, \& Khaled, 2014).

\subsubsection{Halal Label}

The term "halal" is based on the Arabic word that refers to Islamic value. Halal means permitted or lawful by the religion to consume the goods (Latif, Mohamed, Sharifuddin, Abdullah, \& Ismail, 2014) (Rejaii \& Arianfar, 2016). In addition, Islam has ordered their belief to consume halal products, it was written in the Quran "Oye people! East the lawful and good things out of what is in the earth, and do not follow the footsteps of the Shaitan; surely he is your open enemy" (QS: Al-Baqarah: 168). Therefore, the Muslim consumer should purchase everything corresponds to the value of religion (halal) (Alzeer, Rieder, \& Hadeed, 2018). Thus, halal is something important to the Muslim consumer to make a decision whether to purchase it or not (Awan et al., 2015). Moreover, in order to convince the Muslim consumer that the products are "halal" based on the Islamic value, the restaurant should declare the halal label/logo on the product. Nevertheless, the appearance of halal label/ logo on products can help Muslim consumers to be convinced that they buy halal products (Rejaii \& Arianfar, 2016) (Razzaque, Mohamed Abdur, 2016). Therefore, 
the halal label is not only about the lawful food, but also about the hygiene and safety of the food (Shariff \& Lah, 2014) (Razzaque, Mohamed Abdur, 2016).

On the other hand, the halal label determines the Muslim purchase intention toward the halal product (Majid, Sabir, \& Ashraf, 2015) (Aziz \& Chok, 2013). Even though most producers of food are non-Muslim, as long as the packaging has the halal label, Muslim consumers will purchase it (Azam, 2016). As a result, halal label/logo becomes the consideration of Muslim consumers to make a decision (Muhamad, Nazlida, Vai Shiem, Leong, 2017). In contrast, the absence of the halal logo/label could affect the business performance (Shariff \& Lah, 2014).

\subsubsection{Habit}

Habit is a psychology construct. Habit is defined as the repeated activity in stable behavior (Ouellette \& Wood, 1998) (Beatty \& Kahle, 1988). The strength of individual habit contains the history of repetition of behavior, the effort to control the behavior, the absence of awareness, the identity element, and efficiency (Verplanken \& Orbell, 2003). In addition, habitual behavior appears ineffective way, effortlessly, and automatically (Aarts, Verplanken, \& Van Knippenberg, 1998). However, (C. F. Chen \& Chao, 2011) assumed that habit is reasoned action, as opposed to something that appears automatically. However, the habit may be developed under the frequency of past behavior and is considered indicative of future behavior (Ouellette \& Wood, 1998). Therefore, the history of activity in the past constructs the habit in the present activity, as the habit has an important role in correlation with behavior (Beatty \& Kahle, 1988).

In the context of technology acceptance, habit plays a significant role. It influences the use of technology and mediates the influence of intention in technology use (Limayem, Hirt, \& Cheung, 2007) (Venkatesh, Viswanath, James Y.L Thong, 2012). Meanwhile, the intention to use the technology based on the level of the habit (Limayem, Hirt, \& Chin, 2001). Furthermore, the use of technology is not only mediated by the habit, but also the satisfaction of the technology use (Aarts et al., 1998) (Verplanken \& Orbell, 2003) (Lankton, Wilson, \& Mao, 2010). As long as the technology provides satisfaction to the user, the user will possibly repeat using the technology.

\subsection{Previous Studies}

In this study we attempt to investigate the Muslim customer behavior in purchasing online halal food by using TAM model as basic and additional external variable, which suits to the Muslim customer. In fact, a number of previous studies have been conducted on online customer behavior by using TAM model. In addition, perceived usefulness and perceived of use are statistically significant to the acceptance of purchase intention, online grocery, and mobile commerce (Renny et al., 2013) (Ashraf et al., 2014) (Chen et al., 2017) (Natarajan et al., 2018)(Chi, 2018)(Driediger \& Bhatiasevi, 2019) (Akhlaq \& Ahmed, 2015). At the same time, (Hansen et al., 2018) stated that perceived ease of use positively moderates the perceived behavioral control on social media transaction. In contrast, (Jin et al., 2016) (Agrebi \& Jallais, 2015) (Tong, 2010) (Wu \& Wang, 2005) found that only 
perceived usefulness have positive influence to mobile shopping behavior. Moreover, perceived usefulness and perceived ease of use have significantly mediated the attitude and purchase intention (Ashraf et al., 2016)(Wu \& Ke, 2015). Further, perceived usefulness have a significant influence to purchase intention among Muslim customer (Jamal \& Sharifuddin, 2015). However, (Shang, Dawei, $\mathrm{Wu}, 2017)$ found that only perceived ease of use is significantly influenced the mobile shopping.

On the other hand, a Muslim customer should consume everything allowed by the religion. Therefore, religious people are driven by its religious conduct to behave. Numerous study revealed that religious knowledge influence the purchase intention (Jamal \& Sharifuddin, 2015)(Majid et al., 2015) (Newaz, Farhana, Fam, Kim-Shyan, Revti, 2016) (Sukesti, Fatmasari \& Mamdukh, 2014)(Butt, Rose, Stephen, 2015). In addition, (Henderson, 2016) (Abd Rahman et al., 2015)(Minton et al., 2018) (Mohd Suki \& Mohd Suki, 2015) (Varinli et al., 2016)(Nor, Latif, Ismail, \& Nor, 2016)(Awan et al., 2015) stated that religious knowledge drives Muslim behavior toward consuming general food or halal food. Nonetheless, religious knowledge influences the purchase intention of halal-labeled product such as food, cosmetics and tourism (Jamal \& Sharifuddin, 2015)(Majid et al., 2015)(Razzaque, Mohamed Abdur, 2016)(Khan, Asad, \& Mehboob, 2017)(Muhamad, Nazlida, Vai Shiem, Leong, 2017) (Briliana \& Mursito, 2017)(Aisyah, 2014). Thus, the halal label is an important aspect of a product to the Muslim customer. Therefore, halallabeled products influence the purchase intention of Muslim customer (Aziz \& Chok, 2013) (Hamdan, Issa, Abu, \& Jusoff, 2013) (Dharma et al., 2018).

Furthermore, the online shopping behavior has become a habit (Taylor, Pahnila, \& Warsta, 2010). (Law et al., 2016) found that habitual online use as the key mediators of purchase intention. Meanwhile (D. Amoroso \& Lim, 2017) showed that habit mediates between customer satisfaction and continuance intention. However, (Farivar Samira, Ofir Turel, 2017) revealed that habit as moderator weaken the nexus between commerce risk and purchase intention. Moreover, habit as mediator strengthens the influence between perceived value and repurchase intention, whereas trust and satisfaction are weakened by the habit (Hsu et al., 2015). In contrast, (Chiu, Hsu, Lai, \& Chang, 2012) revealed that a high level of habit reduces the effect of trust on repurchase intention.

\subsection{Conceptual Framework}

In this paper, we analyze the purchase intention of the Muslim consumer in purchasing online halal food. The proposed model is adapted from the technology acceptance model (TAM) which developed by (Davis, 1989). 
Figure 1. The Conceptual Framework

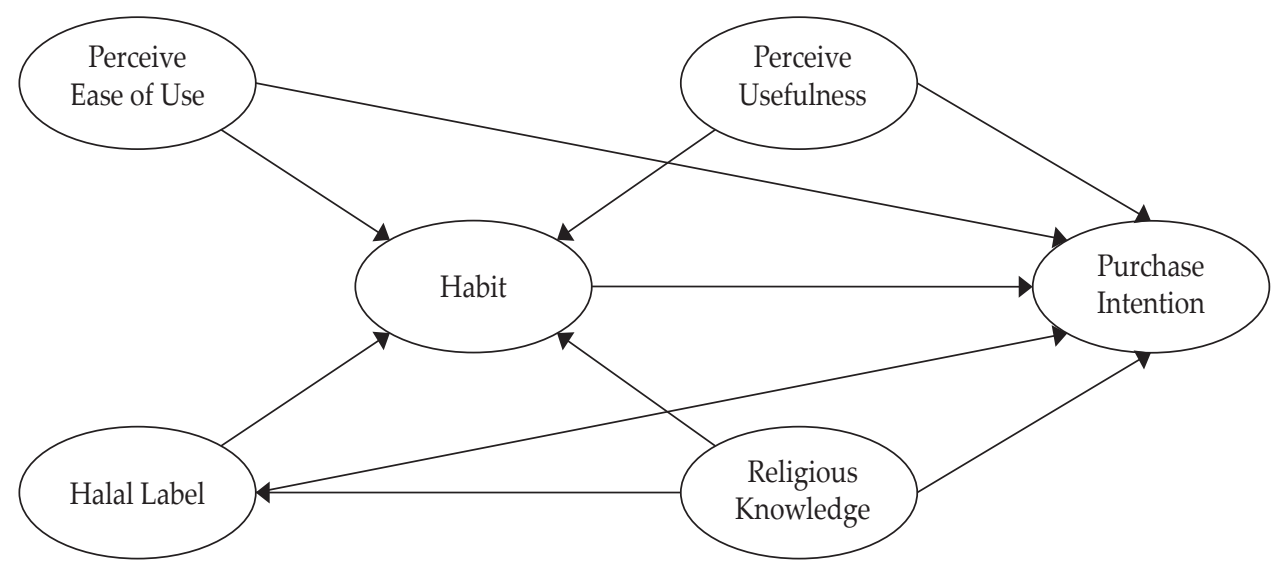

The model shows the PLS-path model with six latent variables, with perceived usefulness and perceived ease of use as the origin of TAM model latent variables. Then, we add religious knowledge, halal label, and habit as new latent variables. In addition, we include habit as mediation construct between independent exogenous latent variables and dependent endogenous latent variable.

To examine the direct relationships between independent exogenous latent variables (perceived usefulness, perceived ease of use, religious knowledge and halal label) and dependent endogenous latent variable (purchase intention), four hypotheses are developed. In addition, we examine indirect relationship between independent exogenous latent variables and dependent endogenous latent variables with the mediating role of variable habit to purchase intention. We also investigate the indirect nexus between religious knowledge and habit with using halal label as mediation. Finally, we have eleven developed hypotheses to examine the relationship among variables.

\section{METHODOLOGY}

\subsection{Data}

In this paper, we analyze the purchase intention of the Muslim consumer in purchasing halal food through technology. We use primary data collected from a self-administered questionnaire. The questionnaire was classified into two sections. The first section described the demographic information of respondents. The second explained 27 components relating to the variables. We used the Likert scale ranging from 1 (strongly disagree) to 4 (strongly agree). The population of the samples is the Muslim customers. We used the random sampling technique to determine the samples. Furthermore, the questionnaires were shared online through Google Form. At the end of data collection, 127 questionnaire answers were collected for further analysis. 


\subsection{Model Development}

\subsubsection{TAM}

The model development of this study is shown in Fig. 1. We modified the origin of TAM model by adding external variables (religious knowledge, halal label and habit). (Davis, 1989) argued that people accept the technology by two major reasons: the first is perceived usefulness (PU), and the second perceived ease of use. Perceived usefulness refers to the degree to which using particular technology will enhance their performance. Meanwhile, perceived ease of use (PEOU) refers to the degree to which using particular technology will effortless (Davis, 1993). In this digital era, the purchase behavior of human beings is shaped by technology.

Since such development, customers can purchase the food through online form including Muslim customer. Empirical studies showed that perceived usefulness and perceived ease of use affect the purchase intention (Driediger \& Bhatiasevi, 2019)(Natarajan et al., 2018)(Chi, 2018)(Y. Chen et al., 2017). In addition, habit plays a significant role in technology use behavior (Limayem et al., 2001). Therefore, the usefulness and the easiness of technology lead the human behavior to habitual activity. Thus, the difference level of habit should change the use behavior (Limayem et al., 2007). To sum up, the hypotheses are:

$\mathrm{H1}$ : perceived usefulness positively influence to the purchase intention

$\mathrm{H} 2$ : perceived ease of use positively influence the purchase intention

H3: Perceived usefulness positively influence the habit

H4: perceived ease of use positively influence the habit

\subsubsection{Religious Knowledge}

Religious knowledge refers to the person who believes in their value of religion and apply it in their daily activity (Razzaque, Mohamed Abdur, 2016). Therefore, Religious knowledge shapes the behavior of religious people (Agag \& El-masry, 2016). (Swimberghe et al., 2009) stated that religious commitment influence the customer loyalty. At the same time, (Chairy, 2012) revealed that spirituality influences the green purchase intention. Furthermore, religious knowledge statistically influences Islamic home financing (Alam et al., 2012)(Amin et al., 2014). Nonetheless, religious commitment has a significant effect to purchase halal endorsed product (Khan et al., 2017). The Muslim should behave under the religious conduct in all activities, including in food consumption (Quantaniah, Noreina, \& Nurul, 2013). Thus, behavior in food consumption is part of Muslim habit and identity (Varinli et al., 2016). In terms of consumption, a Muslim prefers to consume the halal-labeled product, rather than the absence of it (Awan et al., 2015). Moreover, religious knowledge affects positively on halal food preferences (Yener, 2015). Although, religious knowledge moderates the relationship between horizontal collectivism and intention (Jamal \& Sharifuddin, 2015). Thus, the following hypotheses were developed:

H5: religious knowledge positively affects purchase intention

H6: religious knowledge positively affects halal label

H7: religious knowledge positively affects habit 


\subsubsection{The Halal Label}

The halal label is important for the Muslim customer when purchasing halal food (Shariff \& Lah, 2014) (Razzaque, Mohamed Abdur, 2016) (Rejaii \& Arianfar, 2016). Therefore, consuming halal-labeled product become a habit for Muslim consumer (Varinli et al., 2016). Moreover, numbers of empirical investigation revealed that halal label significantly affect purchase intention (Sukesti, Fatmasari \& Mamdukh, 2014)(Ghadikolaei, 2016)(Aziz \& Chok, 2013) (Dharma et al., 2018) (Abdul Latiff, Rezai, Mohamed, \& Amizi Ayob, 2016). In addition, (Hamdan et al., 2013) revealed that awareness of halal labeling affects the purchase intention. Moreover, (Mohayidin \& Kamarulzaman, 2014) found that the halal-label gained the most important attribute in consumer preferences. Furthermore, halal certification influences the intention of cosmetics consumer (Majid et al., 2015). Therefore, we hypothesized that:

H8: halal label positively affects purchase intention

H9: halal label positively affects habit

\subsubsection{Habit}

Habit refers to action sequences, originally intentional, repeated behavior without conscious intention (de guinea, 2009). In this internet era, continuing use behavior of technology shapes the habitual behavior (David, 2003) (Lankton et al., 2010) (Narwal, Mahabir, geeta, 2013) (Hsiao, Chang, \& Tang, 2015)(D. Amoroso \& Lim, 2017). Regarding the purchase intention of online halal food, habit plays a significant role. A number of empirical investigations on habit and purchase intention have increased. (Hsiao et al., 2015) (Amoroso \& Lim, 2017) stated that habit mediates between satisfaction and continuing intention. In contrast, (Farivar Samira, Ofir Turel, 2017) revealed that habit moderates (weaken) between commerce risk and purchase intention. Moreover, low level of habit moderates trust and satisfaction to repeat purchase intention (Hsu et al., 2015). Furthermore, habit affects negatively to switching intention toward public transport (C. F. Chen \& Chao, 2011). Nonetheless, consumers habit influences the intention to accept halal product(Rahim \& Junos, 2012). However, the use of online shopping behavior had become habitual behavior (Taylor et al., 2010). Therefore, the developed hypotheses are:

H10: habit affects positively purchase intention

H11: habit mediates between independent variables and dependent variable 
Figure 2.

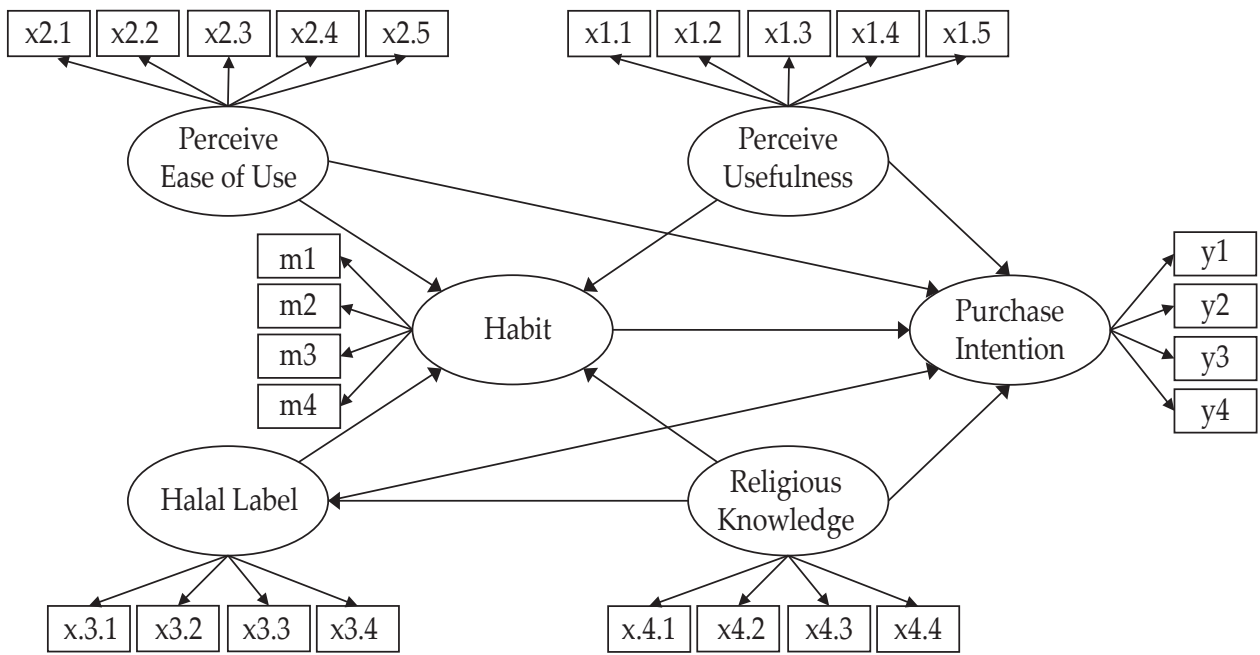

Figure 2 describes the PLS-path model with all instruments of the constructs. Therefore, each construct consists of four or five instruments representing the constructs. Moreover, in order to assure reliability and validity of the data, items and scales were derived from the previous studies. All the items of the constructs were measured using Likert scale ranging from 1 (strongly disagree) to 4 (strongly agree). Furthermore, the explanation of all the items can be seen in Table 1.

Table 1.

Explanation of The Instruments

\begin{tabular}{lll}
\hline Instruments & \multicolumn{1}{c}{ Constructs } & \multicolumn{1}{c}{ References } \\
\hline & Perceive usefulness & \\
x1.1 & The benefit of information system & (Chen \& Chao, 2011)(Driediger \\
x1.2 & Easy to purchase the food & \& Bhatiasevi, 2019) (Chi, 2018) \\
x1.3 & Time efficiency & (Agag \& El-masry, 2016)(Jamal \& \\
x1.4 & Fast transaction & \\
x1.5 & Information system provide many choices & \\
\hline & Perceive ease of use & \\
x2.1 & Easy to learn & (Chen \& Chao, 2011)(Driediger \\
x2.2 & Easy to access & \& Bhatiasevi, 2019) (Chi, 2018) \\
x2.3 & Easy to operate & (Agag \& El-masry, 2016)(Jamal \& \\
x2.4 & Easy to handle & Sharifuddin, 2015) \\
x2.5 & Easy to master & \\
\hline & Halal label & \\
x3.1 & Everyday consumption & (Azam, 2016)(Butt, Rose, Stephen, \\
x3.2 & Assuring the purchase of halal label & 2015) (Awan et al., 2015)(Aziz \& \\
x3.3 & Important thing to consume & Chok, 2013) \\
x3.4 & The existence of halal label on restaurant banner & \\
\hline
\end{tabular}


Table 1.

Explanation of The Instruments (Continued)

\begin{tabular}{|c|c|c|}
\hline Instruments & Constructs & References \\
\hline & Religious knowledge & \multirow{5}{*}{$\begin{array}{l}\text { (Newaz, Farhana, Fam, Kim- } \\
\text { Shyan, Revti, 2016)(Jamal \& } \\
\text { Sharifuddin, 2015)(Agag \& El- } \\
\text { masry, 2016) }\end{array}$} \\
\hline$x 4.1$ & Knowledge of the religious allowance & \\
\hline$x 4.2$ & Knowledge of the religious forbidden & \\
\hline$x 4.3$ & Not consuming forbidden food & \\
\hline \multirow[t]{2}{*}{$x 4.4$} & $\begin{array}{l}\text { Not consuming forbidden food through online } \\
\text { and offline purchasing }\end{array}$ & \\
\hline & Habit & \multirow{5}{*}{$\begin{array}{l}\text { (Khalifa \& Liu, 2007)(Taylor et al., } \\
\text { 2010)(Chen \& Chao, 2011) }\end{array}$} \\
\hline $\mathrm{m} 1$ & Usually act in line with religious teachings & \\
\hline $\mathrm{m} 2$ & $\begin{array}{l}\text { Usually buy halal food through online and } \\
\text { offline }\end{array}$ & \\
\hline m3 & Usually do halal consumption & \\
\hline $\mathrm{m} 4$ & Usually consume halal food & \\
\hline & Purchase intention & \multirow{5}{*}{$\begin{array}{l}\text { (Driediger \& Bhatiasevi, 2019) } \\
\text { (Chi, 2018)(Hansen et al., 2018). }\end{array}$} \\
\hline y1 & Intention to purchase online food & \\
\hline y2 & Intention to purchase due to its easiness & \\
\hline y3 & Intention to purchase due to its benefit & \\
\hline y4 & $\begin{array}{l}\text { Intention to purchase due to its allowed by the } \\
\text { religion }\end{array}$ & \\
\hline
\end{tabular}

\subsection{Methodology}

Once we gathered the data, we used PLS-SEM (partial least squares structural equation modeling) to estimate the structure model. Actually, PLS-SEM is usually used when facing the non-normal data, small sample size and formatively measure constructs (Hair, Sarstedt, Hopkins, \& Kuppelwieser, 2014). In addition, PLS-SEM has two components: the inner model and outer model. PLS-SEM becomes the more familiar tool in the marketing field (Hair, Ringle, \& Sarstedt, 2011). We apply smartPLS 3.0 application to analyze the data.

In the outer model, we estimate the reliability and validity of the constructs. The reliability of the variables measured by the result of composite reliability and the result of Cronbach's alpha. The result of composite reliability must be higher than $>0.70$ and Cronbach's alpha should be higher than $>0.60$ to indicates that the constructs are reliable. Meanwhile, the validity of the variables was assessed by the result of the AVE (Average Variance Extracted). Moreover, to indicate that the variables are valid, the result of AVE must be upper than $>0.50$ (Hair et al., 2011).

Furthermore, we calculated the structural modeling in the inner model. In the structural modeling, we estimate the $R^{2}$ values. Whereas $R^{2}$ values of 0.20 are deliberated in high in a study such as a customer behavior, $R^{2}$ results of $0.75,0.50$, 0,25 , respectively explain the level of influence mediate or weak levels of accuracy prediction (Hair et al., 2014). Thereafter, we estimated the hypothesis testing. Critical $t$-value at significance level $5 \%$ is 1.98 and the $p$-value 0.05 . The hypothesis is accepted when the $t$-value higher than $t$-table $(t$-value $>1.98)$ and $p$-value lower than 0.05 ( $p$-value $\leq 0.05)$, vice versa (Hair et al., 2011). 


\section{RESULTS AND ANALYSIS}

\subsection{Results}

The inner model of PLS-SEM describes the relationship the construct being estimated. On the other hand, the outer model or the assessment model explains the relationship between the indicator variables and their corresponding construct (Hair et al., 2014).

\subsubsection{The Outer Model}

In the outer model, we evaluated the reliability and validity of the data. The measurement of the reliability assessed by composite reliability and Cronbach's $\alpha$. In addition, the measurement of the validity was assessed by average variance constructs (AVE). Cronbach's alpha and composite reliability both explain about internal consistency reliability of construct. the value of Cronbach's alpha should higher than 0.60 to indicate the internal consistency reliability (Hair et al., 2011). In addition, Average Variance Extracted (AVE) points to the convergent validity of the constructs (Hair et al., 2014). The value of AVE must be higher than 0.50 to show the convergent validity of the construct (Hair et al., 2011).

Table 2.

Reliability and Validity of Constructs

\begin{tabular}{lccc}
\hline & $\begin{array}{c}\text { Cronbach's } \\
\text { Alpha }\end{array}$ & $\begin{array}{c}\text { Composite } \\
\text { Reliability }\end{array}$ & $\begin{array}{c}\text { Average Variance } \\
\text { Extracted (AVE) }\end{array}$ \\
\hline habit & 0.937 & 0.956 & 0.844 \\
Halal label & 0.785 & 0.861 & 0.608 \\
perceived ease of use & 0.920 & 0.940 & 0.759 \\
perceived usefulness_ & 0.871 & 0.906 & 0.660 \\
purchase intention & 0.912 & 0.939 & 0.794 \\
religious knowledge & 0.918 & 0.942 & 0.803 \\
\hline
\end{tabular}

Table 2 shows the result of Cronbach's alpha, Composite Reliability, and AVE. All constructs have result above $>0.60$ which indicate that all constructs have internal consistency reliability. The value of habit $0.937>0.60$, Halal Label 0.785 $>0.60$, PEOU (Perceived Ease of Use) 0.920>0.60, PU (Perceived Usefulness) $0.871>0.60$, Purchase Intention 0.912>0.60, and Religious Knowledge 0.918>0.60. Meanwhile, the value of composite reliability of the all constructs is also higher than $>0.70$, the value of habit 0.956 >0.70, Halal Label 0.861 $>0.70$, PEOU (Perceived Ease Of Use) 0.940>0.70, PU (Perceived Usefulness) 0.906>0.70, Purchase Intention 0.939>0.70, Religious Knowledge 0.942>0.70.

Furthermore, the value of Average Variance Extracted (AVE) of the constructs are higher than $>0.50$. the value of habit $0.844>0.50$, Halal Label 0.608 $>0.50$, PEOU $0.759>0.50$, PU 0.660 $>0.50$, Purchase Intention 0.794>0.50, Religious Knowledge $0.803>0.50$. As a result, the value of AVE of constructs indicates that all constructs have strong convergent validity. 


\subsubsection{The Inner Model}

We analyze the $R^{2}$ in the inner model. The value of $R^{2}$ is considered as the predictive accuracy; whereas, $R^{2}$ results of $0.75,0.50$, and 0.25 represent the exogenous variables influencing the endogenous variables.

Table 3.

The $\mathbf{R}^{2}$ Results

\begin{tabular}{lcc}
\hline & R Square & R Square Adjusted \\
\hline habit_ & 0.792 & 0.785 \\
halal label & 0.460 & 0.456 \\
purchase intention & 0.612 & 0.596 \\
\hline
\end{tabular}

Table 3 displays the $R^{2}$ results that represent the predictive accuracy. The $R^{2}$ values of Habit $0.785(78.5 \%)$ have a strong level in predictive accuracy. Meanwhile, the $R^{2}$ results of purchase intention $0.596(59.6 \%)$ indicate the medium level of accuracy prediction. The $\mathrm{R}^{2}$ value of halal label $0.456(45.6 \%)$ indicates the weak level of accuracy prediction. The $R^{2}$ results indicate that $78.7 \%$ of variable habit is influenced by the four independent variables, while the purchase intention variable is $59.7 \%$ influenced by all variables. Accordingly, the halal label variable is $45.6 \%$ is influenced by religious knowledge.

Ultimately, we calculate the hypothesis testing. The proposed hypothesis has a significant value when the $t$-value higher than $t$-table $(t$-value $>1.98)$ and $p$-value lower than 0.05 ( $p$-value $\leq 0.05)$, vice versa. The results are as follows.

Figure 3. Results of The Hypothesis Testing

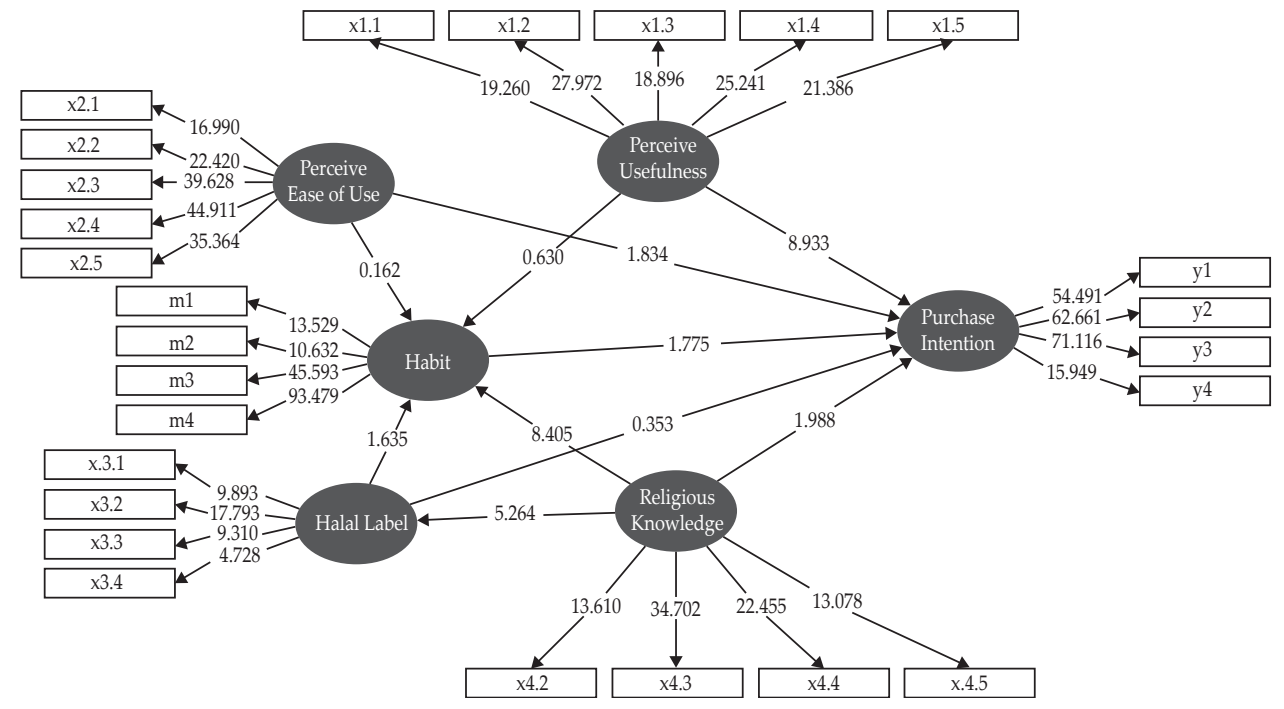


Table 4.

Hypothesis Results Testing

\begin{tabular}{lccc}
\hline & $\begin{array}{c}\text { Original } \\
\text { Sample }(\mathbf{O})\end{array}$ & $\begin{array}{c}\text { T Statistics } \\
(\mid \text { OO/STDEV } \mid)\end{array}$ & P Values \\
\hline habit -> purchase intention & 0.241 & 1.775 & $0.076^{* *}$ \\
halallabel -> habit & 0.166 & 1.635 & 0.103 \\
halallabel -> purchase intention & 0.028 & 0.353 & 0.725 \\
perceived ease of use -> habit & -0.007 & 0.162 & 0.872 \\
perceived ease of use -> purchase intention & 0.149 & 1.834 & $0.067^{* *}$ \\
perceived usefulness_-> habit & -0.021 & 0.630 & 0.529 \\
perceived usefulness_-> purchase intention & 0.689 & 8.933 & $0.000^{*}$ \\
religious knowledge -> habit & 0.771 & 8.405 & $0.000^{*}$ \\
religious knowledge -> halallabel & 0.678 & 5.264 & $0.000^{*}$ \\
religious knowledge -> purchase intention & -0.234 & 1.988 & $0.047^{*}$ \\
\hline
\end{tabular}

*Significance at $5 \%$, ** significance at $10 \%$

Table 4 describes the results of hypothesis. There are four variables which have a significant value: (1) perceived usefulness that affects significantly to purchase intention ( $\mathrm{t}$-value $9.179>1.98$, p-value $0.000 \leq 0.05$ ); (2) religious knowledge that has a positively significant impact to habit (t-value $8.775>1.98$, p-value $0.000 \leq$ 0.05); (3) religious knowledge that has a positively significant influence to halal label ( $\mathrm{t}$-value $5.247>1.98$, p-value $0.000 \leq 0.05$ ); and (4) religious knowledge that has negative significant impact to purchase intention ( $\mathrm{t}$-value $2.086>1.98$, $\mathrm{p}$-value $0.037 \leq 0.05)$. Meanwhile, habit and perceived ease of use have positive influence to the purchase intention, each ( $p$-value $0.076 \leq 0.1)$ and ( $p$-value $0.067 \leq 0.1$ )

In addition, the rest of the constructs have insignificant values. A halal label has positive insignificant impact to habit ( $t$-value $1.630<1.98$, p-value $0.103 \geq 0.05$ ), halal label has positive insignificant impact to purchase intention ( $\mathrm{t}$-value $0.363<$ 1.98 , p-value $0.725 \geq 0.05$ ), perceived ease of use has negative insignificant impact to habit ( $\mathrm{t}$-value $0.157<1.98$, $\mathrm{p}$-value $0.872 \geq 0.05$ ), and perceived usefulness has negative insignificant impact to habit ( $\mathrm{t}$-value $0.613<1.98$, $\mathrm{p}$-value $0.529 \geq 0.05$ ).

Table 5.

Indirect effect

\begin{tabular}{|c|c|c|c|}
\hline & $\begin{array}{l}\text { Original } \\
\text { Sample }\end{array}$ & T Stat. & P-Values \\
\hline religious knowledge -> halallabel $->$ habit & 0.112 & 1.559 & 0.120 \\
\hline halallabel -> habit -> purchase intention & 0.040 & 1.014 & 0.311 \\
\hline religious knowledge -> halallabel -> habit $->$ purchase intention & 0.027 & 0.919 & 0.359 \\
\hline perceived ease of use -> habit -> purchase intention & -0.002 & 0.137 & 0.891 \\
\hline perceived usefulness_-> habit -> purchase intention & -0.005 & 0.471 & 0.638 \\
\hline religious knowledge -> habit -> purchase intention & 0.186 & 1.683 & $0.093^{* *}$ \\
\hline religious knowledge -> halallabel -> purchase intention & 0.019 & 0.337 & 0.736 \\
\hline
\end{tabular}

${ }^{*} \mathrm{P}$ value $<0.05,{ }^{* *} \mathrm{P}$ value $<0.1$ 
Furthermore, in this study, we consider variable habit as mediating variable, which mediates between the independent variables and dependent variable. Therefore, we estimate whether the habit will fully mediate the independent variables or partly mediate the independent variables to a dependent variable.

The results in table 5 explain the role of variable habit in order to mediate between independent variables (PU, PEOU, halal label, religious knowledge) and dependent variable (purchase intention). Then, the role of the halal label variable is to mediate between religious knowledge and purchase intention. The result of mediating variable halal label between religious knowledge and habit is 0.120 $\leq 0.05$. The result of mediating variable halal label and habit between religious knowledge and purchase intention is $0.311 \leq 0.05$. The result of mediating variable habit between perceived ease of use and purchase intention is $0.891 \leq 0.05$. The value of mediating variable habit between perceived usefulness and purchase intention is $0.638 \leq 0.05$. The value of mediating variable habit between religious knowledge and purchase intention is $0.093 \leq 0.05$. The value of mediating variable halal label between religious knowledge and purchase intention is $0.736 \leq 0.05$. The results indicate that variable habit does not mediate the PU, PEOU, and halal label. Only religious knowledge is mediated by habit to purchase intention. Therefore, the variable halal label also does not mediate between religious knowledge and purchase intention, religious knowledge, and habit. Moreover, halal label and habit both do not mediate religious knowledge and purchase intention.

\subsection{Analysis}

Our findings yield perceived usefulness has a significant positive impact directly to purchase intention. This result is in line with (Wu \& Ke, 2015)(Kusyanti \& Arifin, 2017) (Koufaris, 2002)(Mathieson, 1991)(Wu \& Wang, 2005)(Driediger \& Bhatiasevi, 2019)(Jin et al., 2016). At the same time perceived usefulness has a positive effect on habit but insignificant. The finding indicates that the advantages is the key driver to use the application in order to predict technology acceptance (Davis, 1989). However, the usefulness of application in purchasing online halal food does not lead the Muslim consumer to habitual activity. According to (Lankton et al., 2010) (D. Amoroso \& Lim, 2017) habit is correlated with attitudes and satisfaction of consumers. In contrast, the Muslim consumer will purchase online halal food depend on their actual behavior, rather than habitual behavior (Limayem et al., 2001), such as facing the limitation of time during break time of work.

Meanwhile, the perceived ease of use has a significant positive influence to purchase intention. This finding supported by (Ashraf et al., 2014)(Renny et al., 2013)( Wu \& Ke, 2015)(Driediger \& Bhatiasevi, 2019). In contrast, according to (Zhang, Zhao, \& Tan, 2008) (Karahanna \& Straub, 1999) (Koufaris, 2002) (J. H. Wu \& Wang, 2005) perceived ease of use insignificantly influences the purchase intention. However, the easiness of technology use in helping daily activity determines the decision of purchase intention including Muslim consumer.

However, Muslim consumers that embed religious knowledge in their activity will rely on their activity in line with the religious norm. Instead of consuming any food, the Muslim consumer should consume the food in a halal way (Minton et al., 2018) (Simanjuntak \& Dewantara, 2014), even when they purchase it on online 
form. Our finding revealed that religious knowledge has a negative significant effect to purchase intention. The higher knowledge of religious people, the lesser in purchase intention.

Thus, in Islam, a Muslim should not consume excessively (tadzbir) as written in the Quran "and give to the near of kin his due and to the needy and wayfarer and do not squander wastefully. Surely the squanderers are the fellows of the Shaitan and the Shaitan is ever ungrateful to his Lord (Al-Israa:26-27). In contrast, (Varinli et al., 2016) (Khan et al., 2017) (Sukesti, Fatmasari \& Mamdukh, 2014) (Yener, 2015) (Jamal \& Sharifuddin, 2015) (Alam et al., 2012) (Delener, 1990) revealed that religious knowledge has positive impact to purchase intention.

On the other hand, religious knowledge has a positive significant impact on the halal label. As mentioned earlier that religious knowledge influences the behavior of religious people. This empirical finding in line with (Simanjuntak \& Dewantara, 2014) (Sukesti, Fatmasari \& Mamdukh, 2014) (Yener, 2015) (Jamal \& Sharifuddin, 2015) (Awan et al., 2015) (Minton et al., 2018). The phenomena seem to make sense in order to convince the Muslim consumer that they purchase a halal food (Shariff \& Lah, 2014). Thus, the halal label for the Muslim consumer is part of the religious issue which can change their behavior (Aisyah, 2014) (Khan et al., 2017). In addition, religious knowledge which embeds to Muslim perspective lead the Muslim to become a habit (Rahim \& Junos, 2012). Therefore, religious knowledge also has a positive significant effect to habit.

A halal label on the food package will increase the confidence of Muslim consumer in purchasing halal food (Aisyah, 2014). Therefore, numerous studies found that halal label has significant influence to purchase intention (Khan et al., 2017)(Ghadikolaei, 2016) (Sukesti, Fatmasari \& Mamdukh, 2014)(Awan et al., 2015)(Aziz \& Chok, 2013). On the contrary, our findings revealed that halal label has insignificant impact to purchase intention. Thus, Muslim consumer makes their decision based on their familiarity of the product, rather than the halal label on it (Hamdan et al., 2013). Moreover, in order to purchase online halal food Muslim consumer is faced the absence of the halal label on the restaurant's banner promoted online. Furthermore, the halal label has insignificant effect to habit. However, in the case of purchasing online halal food, the halal label is not something to address with the Muslim consumer due to the absence of a halal label on the restaurant's banner promoted online. In addition to this, Muslim consumers alternatively purchase the food from the well-known restaurant that provides halal food in the absence of the halal label.

Habit is psychological terms rather than the frequency of past behavioral (Verplanken \& Orbell, 2003). In contrast, the frequency of past behavior becomes a habit in accordance with information system use (Limayem et al., 2007). We found that habit has the significant positive impact to purchase intention. This finding was in line with (Khalifa \& Liu, 2007) (David, 2003) (Limayem et al., 2007) (Limayem et al., 2001). Therefore, (C. F. Chen \& Chao, 2011) argued that habit can switch the behavioral intention. Meanwhile (D. Amoroso \& Lim, 2017) stated that habit has positive influence to continuance intention. Furthermore, in term of purchasing online halal food Muslim consumer has become habitual behavior. In addition, on the mediating effect of PU, PEOU, religious knowledge and halal label on habit, the results revealed that there is no significant value. 


\section{CONCLUSION AND RECOMMENDATION}

\subsection{Conclusion}

This study examined the Muslim consumer behavior in purchasing online halal food. The result shows that perceived usefulness affects positively significant to purchase intention ( $p$-value $0.000<0.05$ ). Therefore, religious knowledge affects significantly to habit ( $\mathrm{p}$-value $0.000<0.05)$. Moreover, religious knowledge affects significantly to halal label ( $\mathrm{p}$-value $0.000<0.05$ ). Furthermore, religious knowledge has negative significant effect to purchase intention ( $p$-value $0.047<0.05)$. On the other hand, habit has positive significant effect to purchase intention ( $p$-value $0.076<0.1)$. At the same time, perceived ease of use has positive significant effect to purchase intention (p-value $0.067<0.1$ ).

In contrast, halal label has positive insignificant effect to habit ( $p$-value $0.103>0.05)$. Therefore, halal label has positive insignificant effect to purchase intention ( $\mathrm{p}$-value $0.725>0.05$ ). Moreover, perceived ease of use has negative insignificant effect to habit ( $p$-value $0.872>0.05$ ). Perceived usefulness has negative insignificant effect to habit ( $p$-value $0.529>0.05$ ). Furthermore, we also estimate habit as mediating variable, the result shows that habit partly mediates between religious knowledge and purchase intention. However, habit has failed to mediate between independent variables (perceived usefulness, perceived ease of use, religious knowledge and halal label) and dependent variable (purchase intention). Therefore, the halal label also failed to mediate between religious knowledge and habit.

The results of this study indicate that Muslim behavior in purchasing online halal food is driven by perceived usefulness. Meanwhile, habitual behavior of Muslim customer is driven by their religious knowledge. Therefore, religious knowledge of a Muslim customer influences the purchase intention negatively, which signifies that the more religious customer the less religious people to purchase online halal food. Furthermore, a Muslim customer depends on their actual behavior rather than habitual behavior when purchasing halal food online. However, further research is necessary, as an investigation of Muslim behavior in other countries is important. To compare the data across generation is needed.

\subsection{Recommendation}

This study offers practical implications. For the researcher, the empirical findings of this study could fill the gap of existing literature. For the practitioners, the company should consider launching the online version in order to attract more customers due to the Muslim consumer's concern about the advantages of technology. Therefore, the halal label is important to guarantee the customer that they in fact purchase halal food. For the regulators, the authority of halal certification must be more inclusive in order to accommodate the small medium enterprises to get halal certification from the authority. Then, the industry should consider halal marketing to attract a wider range of Muslim customers, considering their behavior is driven by the knowledge of the religion. 


\section{REFERENCES}

Aarts, H., Verplanken, B., \& Van Knippenberg, A. (1998). Predicting behavior from actions in the past: Repeated decision making or a matter of habit? Journal of Applied Social Psychology, 28(15), 1355-1374. https://doi. org/10.1111/j.1559-1816.1998.tb01681.x

Abd Rahman, A., Asrarhaghighi, E., \& Ab Rahman, S. (2015). Consumers and halal cosmetic products: Knowledge, religiosity, attitude and intention. Journal of Islamic Marketing, 6(1), 148-163. https://doi.org/10.1108/JIMA-09-2013-0068

Abdul Latiff, Z. A. Bin, Rezai, G., Mohamed, Z., \& Amizi Ayob, M. (2016). Food Labels' Impact Assessment on Consumer Purchasing Behavior in Malaysia. Journal of Food Products Marketing, 22(2), 137-146. https://doi.org/10.1080/1045 4446.2013.856053

Agag, G., \& El-masry, A. A. (2016). Computers in Human Behavior Understanding consumer intention to participate in online travel community and effects on consumer intention to purchase travel online and WOM : An integration of innovation diffusion theory and TAM with trust. Computers in Human Behavior, 60, 97-111. https://doi.org/10.1016/j.chb.2016.02.038

Agrebi, S., \& Jallais, J. (2015). Journal of Retailing and Consumer Services Explain the intention to use smartphones for mobile shopping. Journal of Retailing and Consumer Services, 22, 16-23. https://doi.org/10.1016/j.jretconser.2014.09.003

Aisyah, M. (2014). the Influence of Religious Behavior on Consumers' Intention To Purchase Halal-Labeled Products. Business and Entrepreneurial Review, 14(1), $15-32$.

Akhlaq, A., \& Ahmed, E. (2015). Digital commerce in emerging economies Factors associated with online. https://doi.org/10.1108/IJoEM-01-2014-0051

Alam, S. S., Janor, H., Zanariah, Wel, C. A. C., \& Ahsan, M. N. (2012). Is Religiosity an important factor in influencing the intention to undertake Islamic home financing in Klang Valley? World Applied Sciences Journal, 19(7), 1030-1041. https://doi.org/10.5829/idosi.wasj.2012.19.07.392

Alzeer, J., Rieder, U., \& Hadeed, K. A. (2018). Rational and practical aspects of Halal and Tayyib in the context of food safety. Trends in Food Science and Technology, 71(November 2017), 264-267. https://doi.org/10.1016/j.tifs.2017.10.020

Amin, H., Abdul-Rahman, A. R., \& Razak, D. A. (2014). Theory of Islamic consumer behaviour: An empirical study of consumer behaviour of Islamic mortgage in Malaysia. Journal of Islamic Marketing, 5(2), 273-301. https://doi.org/10.1108/ JIMA-06-2013-0042

Amoroso, D. L., \& Hunsinger, S. (2009). Measuring the Acceptance of Internet Technology by Consumers. International Journal of E-Adoption, 1(3), 48-81. https://doi.org/10.4018/jea.2009092903

Amoroso, D., \& Lim, R. (2017). International Journal of Information Management The mediating e ff ects of habit on continuance intention, 37(January), 693-702. https://doi.org/10.1016/j.ijinfomgt.2017.05.003

Ashraf, A. R., Thongpapanl, N. (Tek), \& Auh, S. (2014). The Application of the Technology Acceptance Model Under Different Cultural Contexts: The Case of Online Shopping Adoption. Journal of International Marketing, 22(3), 68-93. https://doi.org/10.1509/jim.14.0065 
Ashraf, A. R., Thongpapanl, N. (Tek), \& Spyropoulou, S. (2016). The connection and disconnection between e-commerce businesses and their customers: Exploring the role of engagement, perceived usefulness, and perceived easeof-use. Electronic Commerce Research and Applications, 20, 69-86. https://doi. org/10.1016/j.elerap.2016.10.001

Awan, H. M., Siddiquei, A. N., Haider, Z., Sarkis, J., Sarkis, J., Alon, a, \& Dwyer, P. (2015). Factors affecting Halal purchase intention-evidence from Pakistan's Halal food sector. Management Research Review, 38(6). https://doi.org/10.1108/ MRR-01-2014-0022

Azam, A. (2016). An empirical study on non-Muslim's packaged halal food manufacturers. Journal of Islamic Marketing, 7(4), 441-460. https://doi. org/10.1108/JIMA-12-2014-0084

Aziz, Y. A., \& Chok, N. V. (2013). The Role of Halal Awareness, Halal Certification, and Marketing Components in Determining Halal Purchase Intention Among Non-Muslims in Malaysia: A Structural Equation Modeling Approach. Journal of International Food and Agribusiness Marketing, 25(1), 1-23. https://doi.org/10.1 080/08974438.2013.723997

Beatty, S. E., \& Kahle, L. R. (1988). Alternative Hierachies of the Attitude-Behavior Relationship: The Impact of Brand Communitment and Habit. Journal of the Academy of Marketing Science, 16(2), 1-10. https://doi.org/10.1007/BF02723310

Bhuian, Shahid Nakib, sujeet, Kumar Sharma, Irfan Butt, Zafar, U. A. (2017). Antecedents and pro-enviromental consumer behavior (PECB): the moderating role of religiosity. Journal of Consumer Marketing, 33(3). https://doi.org/https:// doi.org/10.1108/ JCM-02-2017-2076

Briliana, V., \& Mursito, N. (2017). Exploring antecedents and consequences of Indonesian Muslim youths' attitude towards halal cosmetic products: A case study in Jakarta. Asia Pacific Management Review, 22(4), 176-184. https://doi. org/10.1016/j.apmrv.2017.07.012

Butt, Rose, Stephen, J. (2015). MNCs and religious influences in global markets : drivers of consumer-based halal brand equity.

Chairy. (2012). Spirituality, Self Transcendence, and Green Purchase Intention in College Students. Procedia - Social and Behavioral Sciences, 57, 243-246. https:// doi.org/10.1016/j.sbspro.2012.09.1181

Chen, C. F., \& Chao, W. H. (2011). Habitual or reasoned? Using the theory of planned behavior, technology acceptance model, and habit to examine switching intentions toward public transit. Transportation Research Part F: Traffic Psychology and Behaviour, 14(2), 128-137. https://doi.org/10.1016/j. trf.2010.11.006

Chen, Y., Hsu, T., \& Lu, Y. (2017). Journal of Retailing and Consumer Services Impact of fl ow on mobile shopping intention. Journal of Retailing and Consumer Services, (March 2016), 0-1. https://doi.org/10.1016/j.jretconser.2017.04.004

Chi, T. (2018). Journal of Retailing and Consumer Services Understanding Chinese consumer adoption of apparel mobile commerce : An extended TAM approach. Journal of Retailing and Consumer Services, 44(April), 274-284. https:// doi.org/10.1016/j.jretconser.2018.07.019

Chiu, C. M., Hsu, M. H., Lai, H., \& Chang, C. M. (2012). Re-examining the influence of trust on online repeat purchase intention: The moderating role of 
habit and its antecedents. Decision Support Systems, 53(4), 835-845. https://doi. org/10.1016/j.dss.2012.05.021

David, G. (2003). TAM or Just Plain Habit : A Look at Experienced Online Shoppers, 15(3), 1-13.

Davis, F. D. (1989). Perceived Usefulness, Perceived Ease of Use, and User Acceptance of lnformation Technology. MIS Quarterly, 13(3), 319-340. https:// doi.org/10.2307/249008

Davis, F. D. (1993). User acceptance of information technology: system characteristics, user perceptions and behavioral impacts. International Journal of Man-Machine Studies. https://doi.org/10.1006/imms.1993.1022

de guinea, M. (2009). Why Break the Habit of a Lifetime? Rethinking the Roles of Intention, Habit, and Emotion in Continuing Information Technology Use, 33(3), 433-444.

Delener, N. (1990). The effects of religious factors on perceived risk in durable goods purchase decisions. Journal of Consumer Marketing, 7(3), 27-38. https:// doi.org/10.1108/EUM0000000002580

Dharma, M., Putra, T., Pembangunan, U., Budi, P., Rossanty, Y., Pembangunan, U., \& Budi, P. (2018). Country of origin as a moderator of halal label and purchase behavior Country of origin as a moderator of halal label and purchase behavior, (January). https://doi.org/10.24052/JBRMR/V12IS02/COOAAMOHLAPB

Driediger, F., \& Bhatiasevi, V. (2019). Journal of Retailing and Consumer Services Online grocery shopping in Thailand: Consumer acceptance and usage behavior. Journal of Retailing and Consumer Services, 48(February), 224-237. https://doi.org/10.1016/j.jretconser.2019.02.005

Farivar Samira, Ofir Turel, Y. Y. (2017). A trust-risk perspective on social commerce use : an examination of the biasing role of habit. https://doi.org/10.1108/IntR06-2016-0175

Ghadikolaei, F. S. (2016). The Effect of Halal Signs and Symptoms on Consumers ' Purchase Intention in Muslim and Non-Muslim Countries- A Review. International Journal of Busines and Management Invention, 5(7), 44-49. Retrieved from www.ijbmi.org

Hair, J. F., Ringle, C. M., \& Sarstedt, M. (2011). PLS-SEM: Indeed a Silver Bullet. The Journal of Marketing Theory and Practice, 19(2), 139-152. https://doi.org/10.2753/ MTP1069-6679190202

Hair, J. F., Sarstedt, M., Hopkins, L., \& Kuppelwieser, V. G. (2014). Partial least squares structural equation modeling (PLS-SEM): An emerging tool in business research. European Business Review, 26(2), 106-121. https://doi.org/10.1108/ EBR-10-2013-0128

Hamdan, H., Issa, Z. M., Abu, N., \& Jusoff, K. (2013). Purchasing Decisions among Muslim Consumers of Processed Halal Food Products. Journal of Food Products Marketing, 19(1), 54-61. https://doi.org/10.1080/10454446.2013.724365

Hansen, J. M., Saridakis, G., \& Benson, V. (2018). Risk, trust, and the interaction of perceived ease of use and behavioral control in predicting consumers' use of social media for transactions. Computers in Human Behavior, 80, 197-206. https://doi.org/10.1016/j.chb.2017.11.010 
Henderson, J. C. (2016). Halal food, certification and halal tourism: Insights from Malaysia and Singapore. Tourism Management Perspectives, 19, 160-164. https:// doi.org/10.1016/j.tmp.2015.12.006

Hsiao, C., Chang, L. J., \& Tang, K. (2015). Exploring the influential factors in continuance usage of mobile social Apps: Satisfaction, habit, and customer value perspectives. TELEMATICS AND INFORMATICS. https://doi. org/10.1016/j.tele.2015.08.014

Hsu, M., Chang, C., \& Chuang, L. (2015). Understanding the determinants of online repeat purchase intention and moderating role of habit: The case of online group-buying in Taiwan. International Journal of Information Management, 35(1), 45-56. https://doi.org/10.1016/j.ijinfomgt.2014.09.002

Jamal, A., \& Sharifuddin, J. (2015). Perceived value and perceived usefulness of halal labeling: The role of religion and culture. Journal of Business Research, 68(5), 933-941. https://doi.org/10.1016/j.jbusres.2014.09.020

Jin, Y., Osman, A., Nizam, S., \& Rahim, A. (2016). Factors Influencing Online Shopping Behavior: The Mediating Role of Purchase Intention. Procedia Economics and Finance, 35(October 2015), 401-410. https://doi.org/10.1016/ S2212-5671(16)00050-2

Juaneda-Ayensa, E., Mosquera, A., \& Murillo, Y. S. (2016). Omnichannel customer behavior: Key drivers of technology acceptance and use and their effects on purchase intention. Frontiers in Psychology, 7(JUL), 1-11. https://doi.org/10.3389/ fpsyg.2016.01117

Karahanna, E., \& Straub, D. W. (1999). The psychological origins of perceived usefulness and ease-of-use. Information and Management, 35(4), 237-250. https:// doi.org/10.1016/S0378-7206(98)00096-2

Khalifa, M., \& Liu, V. (2007). Online consumer retention : contingent effects of online shopping habit and online shopping experience, (January), 780-792. https://doi.org/10.1057/palgrave.ejis.3000711

Khan, M. M., Asad, H., \& Mehboob, I. (2017). Investigating the consumer behavior for halal endorsed products: Case of an emerging Muslim market. Journal of Islamic Marketing, 8(4), 625-641. https://doi.org/10.1108/JIMA-09-2015-0068

Kim, S. H. (2014). A Study on Adoption Factors of Korean Smartphone Users : A Focus on TAM ( Technology Acceptance Model ) and UTAUT ( Unified Theory of Acceptance and Use of Technology ). Advanced Science and Technology Letters, 57(Business 2014), 27-30. https://doi.org/10.14257/astl.2014.57.07

Koufaris, M. (2002). Applying the Technology Acceptance Model and flow theory to online consumer behavior. Information Systems Researchnformation Systems Research, 13(2), 205-223.

Kusyanti, A., \& Arifin, A. (2017). QRishing : A User Perspective, 8(10), 301-309.

Lankton, N. K., Wilson, E. V., \& Mao, E. (2010). Antecedents and determinants of information technology habit. Information and Management, 47(5-6), 300-307. https://doi.org/10.1016/j.im.2010.06.004

Latif, I. A., Mohamed, Z., Sharifuddin, J., Abdullah, A. M., \& Ismail, M. M. (2014). A Comparative Analysis of Global Halal Certification Requirements. Journal of Food Products Marketing, 20(November 2014), 85-101. https://doi.org/10.1080/1 0454446.2014.921869 
Law, M., Kwok, R., \& Mark, N. (2016). An extended online purchase intention model for middle-aged online users. Electronic Commerce Research and Applications. https://doi.org/10.1016/j.elerap.2016.10.005

Lee, Y., Kozar, K. A., Larsen, K. R. T., Lee, Y., Kozar, K. A., \& Larsen, K. R. T. (2003). The Technology Acceptance Model: Past, Present, and Future. Communications of the Association for Information Systems, 12(50), 752-780. https://doi. org/10.1037/0011816

Limayem, Hirt, \& Cheung. (2007). How Habit Limits the Predictive Power of Intention: The Case of Information Systems Continuance. MIS Quarterly, 31(4), 705. https://doi.org/10.2307/25148817

Limayem, M., Hirt, S. G., \& Chin, W. (2001). Intention does not always Matter: The Contingent Role of Habit in IT Usage Behaviour. ECIS 2001 Proceedings, 274286. Retrieved from http://aisel.aisnet.org/ecis2001/56\%5Cnhttp://citeseerx.ist. psu.edu/viewdoc/download?doi=10.1.1.83.2394\&rep=rep1\&type=pdf

Lingyun, Q. I. U., \& Dong, L. I. (2008). Applying TAM in B2C E-Commerce Research : An Extended Model, 13(3), 265-272.

Majid, M. B., Sabir, I., \& Ashraf, T. (2015). Consumer Purchase Intention towards Halal Cosmetics \& Personal Care Products in Pakistan. Global of Research in Business \& Management, 1(1), 45-53.

Marangunić, N., \& Granić, A. (2015). Technology acceptance model: a literature review from 1986 to 2013. Universal Access in the Information Society, 14(1), 8195. https://doi.org/10.1007/s10209-014-0348-1

Mathieson, K. (1991). Predicting user intentions: Comparing the technology acceptance model with the theory of planned behavior. Information Systems Research, 2(3), 173-191. https://doi.org/10.1287/isre.2.3.173

Minton, E. A., Johnson, K. A., \& Liu, R. L. (2018). Religiosity and special food consumption: The explanatory effects of moral priorities. Journal of Business Research, (July). https://doi.org/10.1016/j.jbusres.2018.07.041

Mohayidin, M. G., \& Kamarulzaman, N. H. (2014). Consumers' Preferences Toward Attributes of Manufactured Halal Food Products. Journal of International Food and Agribusiness Marketing, 26(2), 125-139. https://doi.org/10.1080/08974438.20 12.755720

Mohd Suki, N., \& Mohd Suki, N. (2015). Does religion influence consumers' green food consumption? Some insights from Malaysia. Journal of Consumer Marketing, 32(7), 551-563. https://doi.org/10.1108/JCM-02-2014-0877

Muhamad, Nazlida, Vai Shiem, Leong, N. (2017). Does the country of origin of a halal logo matter? The case of packaged food purchases. Review of International Business and Strategy. https://doi.org/https://doi.org/10.1108/RIBS-06-2017-0049

Murat, S., \& Hekimoglu, H. (2012). A study on tam : analysis of customer attitudes in online food ordering system, 62, 1138-1143. https://doi.org/10.1016/j. sbspro.2012.09.195

Narwal, Mahabir, geeta, S. (2013). Impact of Information Technology ( It ) on Consumer Purchase Behavior, (July 2013), 41-54.

Natarajan, T., Balasubramanian, S. A., \& Kasilingam, D. L. (2018). Technology in Society The moderating role of device type and age of users on the intention to use mobile shopping applications. Technology in Society, 53, 79-90. https://doi. org/10.1016/j.techsoc.2018.01.003 
Newaz, Farhana, Fam, Kim-Shyan, Revti, R. (2016). Muslim religiosity and purchase intention of different categories of Islamic financial products, 21(March), 141-152. https://doi.org/10.1057/fsm.2016.7

Nor, M. R. M., Latif, K., Ismail, M. N., \& Nor, M. N. M. (2016). Predominant Factors of Malaysia-Middle East Religious and Cultural Relations From the Perspective of Halal Food Supply Chain. Arabian Journal of Business and Management Review (Oman Chapter), 6(1), 22-38. Retrieved from www.arabianjbmr.com

Nwankwo, S., Hamelin, N., \& Khaled, M. (2014). Consumer values, motivation and purchase intention for luxury goods. Journal of Retailing and Consumer Services, 21(5), 735-744. https://doi.org/10.1016/j.jretconser.2014.05.003

Ouellette, J. A., \& Wood, W. (1998). Habit and intention in everyday life. Psychological Bulletin, 124(1), 54-74.

Pascual-miguel, F. J., Agudo-peregrina, Á. F., \& Chaparro-peláez, J. (2015). In fl uences of gender and product type on online purchasing ๑. Journal of Business Research, 1-7. https://doi.org/10.1016/j.jbusres.2015.01.050

Quantaniah, N. A., Noreina, \& Nurul, S. (2013). Selecting Halal Food: A Comparative Study Of The Muslim And Non Muslim Malaysian Student Consumer. 2nd International Conference on Technology Management, Business and Entrepreneurship, (December), 438-453. https://doi.org/10.7763/IJSSH.2015. V5.413

Rahim, N., \& Junos, S. (2012). The Halal Product Acceptance Model For The Religious Society. Business Management Quarterly Review, 3(1), 17-25.

Razzaque, Mohamed Abdur, S. N. C. (2016). Religiosity and Muslim consumers' decision-making process in a non-Muslim society. International Journal for Researcher Development, 7(1), 63-83. https://doi.org/http://dx.doi.org/10.1108/ MRR-09-2015-0216

Rejaii, M., \& Arianfar, A. (2016). Halal food : A systemic review. Internatinal Journal of PharmTech Research, 9(7), 340-345.

Renny, Guritno, S., \& Siringoringo, H. (2013). Perceived Usefulness, Ease of Use, and Attitude Towards Online Shopping Usefulness Towards Online Airlines Ticket Purchase. Procedia - Social and Behavioral Sciences, 81, 212-216. https:// doi.org/10.1016/j.sbspro.2013.06.415

Shang, Dawei, Wu, W. (2017). Understanding mobile shopping consumers ' continuance intention. https://doi.org/10.1108/IMDS-02-2016-0052

Shariff, S. M., \& Lah, N. A. A. (2014). Halal Certification on Chocolate Products: A Case Study. Procedia - Social and Behavioral Sciences, 121(September 2012), 104-112. https://doi.org/10.1016/j.sbspro.2014.01.1112

Simanjuntak, M., \& Dewantara, M. M. (2014). The Effects of Knowledge, Religiosity Value, and Attitude on Halal Label Reading Behavior of Undergraduate Students. ASEAN Marketing Journal, 6(2), 65-76.

Sohn, S. (2017). Journal of Retailing and Consumer Services A contextual perspective on consumers ' perceived usefulness: The case of mobile online shopping. Journal of Retailing and Consumer Services, 38(January), 22-33. https:// doi.org/10.1016/j.jretconser.2017.05.002

Souiden, N., \& Rani, M. (2015). Consumer attitudes and purchase intention towards islamic bank: The influence of religiosity. International Journal of Bank Marketing, 33(2), 143-161. https://doi.org/10.1108/IJBM-10-2013-0115 
Souiden, Ni. (2014). The impact of Islamic beliefs on consumers' attitudes and purchase intentions of life insurance. International Journal of Bank Marketing, 33(4), 63-83. https://doi.org/https://doi.org/10.1108/IJBM-01-2014-0016

Sukesti, Fatmasari, \& Mamdukh, B. (2014). the Influence Halal Label and Personal Religiousity on Purchase. International Journal of Business, Economics and Law, 4(1), 2012-2015.

Swimberghe, K., Sharma, D., \& Flurry, L. (2009). An exploratory investigation of the consumer religious commitment and its influence on store loyalty and consumer complaint intentions. Journal of Consumer Marketing, 26(5), 340-347. https://doi.org/10.1108/07363760910976592

Taylor, P., Pahnila, S., \& Warsta, J. (2010). Behaviour \& Information Technology Online shopping viewed from a habit and value perspective, (October 2014), 37-41. https://doi.org/10.1080/0144929X.2010.501115

Tong, X. (2010). A cross-national investigation of an extended technology acceptance model in the online shopping context. https://doi. org/10.1108/09590551011076524

Varinli, İ., Erdem, E., Mutlu, Y., Avcılar, Y., \& Avcılar, M. Y. (2016). Exploring the Factors Affecting Purchase Intention of Halal Certified Foods in Turkey: A PLS-Path Modeling Study. European Journal of Business and Management, 8(4), 2222-2839. Retrieved from https://www.researchgate. net/publication/296700568_Exploring_the_Factors_Affecting_Purchase_ Intention_of_Halal_Certified_Foods_in_Turkey_A_PLSPath_..

Venkatesh, Viswanath, James Y.L Thong, X. X. (2012). Consumer Acceptance and Use of Information Technology: Extending the Unified Theory of Acceptance and Use of Technology. Management Information Systems Research Center, 36(1), 157-178.

Venkatesh, V., Morris, M. G., Quarterly, S. M. I. S., Mar, N., \& Morris, M. G. (2000). Why Don ' t Men Ever Stop to Ask for Directions ? Gender, Social Influence, and Their Role in Technology Acceptance and Usage Behavior. MIS Quarterly, 24(1), 115-139.

Verplanken, B., \& Orbell, S. (2003). Reflections on Past Behavior: A Self-Report Index of Habit Strength. Journal of Applied Social Psychology, 33(6), 1313-1330. https://doi.org/10.1111/j.1559-1816.2003.tb01951.x

Wu, J. H., \& Wang, S. C. (2005). What drives mobile commerce? An empirical evaluation of the revised technology acceptance model. Information and Management, 42(5), 719-729. https://doi.org/10.1016/j.im.2004.07.001

Wu, W.-Y., \& Ke, C.-C. (2015). An Online Shopping Behavior Model Integrating Personality Traits, Perceived Risk, and Technology Acceptance. Social Behavior and Personality: An International Journal, 43(1), 85-97. https://doi.org/10.2224/ sbp.2015.43.1.85

Yener, D. (2015). Factors That Affect the Attitudes of Consumers Toward HalalCertified Products in Turkey. Journal of Food Products Marketing, 21(2), 160-178. https://doi.org/10.1080/10454446.2013.843483

Zhang, S., Zhao, J., \& Tan, W. (2008). Extending TAM for Online Learning Systems: An Intrinsic Motivation Perspective. Tsinghua Science and Technology, 13(3), 312-317. https://doi.org/10.1016/S1007-0214(08)70050-6 